\title{
FUNERAL AND MAGICAL RITUALS AMONG THE KOMI
}

\section{Galina Misharina}

\begin{abstract}
The article dwells upon two types of Komi ritual lamentation: funeral laments and the ones used for expelling bedbugs from the house or for ridding the fields of burdock. The focus is on the magic aspect of ritual lamentation, together with the analysis of the genres of laments within protective rites - although the texts used in such rites actually operate as charms and incantation, the context of the custom reveals a number of elements which are intrinsic of the logic of presenting laments. The author comes to the conclusion, by way of analysing the texts performed at funerals and ward-off rites that besides the poesy, uniform popular terminology and recitative presentation, these texts have similar performing characteristics and unitary magic. As an integrated whole, these characteristics make it possible to use the same terminology with regard to the texts used in protective magic rites and the ones of funeral customs.
\end{abstract}

Key words: charms, funeral customs, Komi people, laments, warding-off rites

Lamentations are categorised according to their function, i.e. funeral, wedding and soldier's laments when being recruited. The ones performed outside a certain ceremony are referred to as non-ritual laments, performed during the events of everyday life. The most archaic and the best known in many cultures are lamentations to the dead, folklorists presume that at first lamentations to the dead reminded of recitation/charming,/enchanting, whereas the one who performed them acted as a shaman escorting the souls (Psychopomp) (Honko 1978: 80-96; Nenola 1978: 77).

According to Kirill Chistov's theory, the genre of lamentations was transferred to other rituals, associated with sending away and receipt, and developed into an independent form that can exist outside rituals and can be performed according the relevant need, e.g. when reminiscing and mourning a close person. Chistov refers to the northern part of Russia, and the habitats of Finno-Ugric peoples, where the tradition of lamenting was particularly pronounced and where the above-mentioned hypothetical process can indeed be observed (Chistov 2005: 189).

A universal set of ritual lamentations has been recorded among the Komi Zyrians, however, they also tend to have lamentations which are little known 
by other peoples or not at all - these are the lamentations performed when warding off insects from the house, expelling weeds in the fields; during economic undertakings, e.g. when building a house, or when cultivating or processing cereals. For example, the Komi lamented prior to crossing a wide river; when ice was breaking up, and during major feasts, e.g. Radunitsa ${ }^{1}$ and Easter.

This article focuses on two types of lamentations among the Komi: laments for the dead and the ones preformed during warding-off rites (e.g. expelling bedbugs from the house and burdock from the fields).

Lamenting at funerals is supposedly a familiar custom for the reader, however, lamenting when warding off weeds and parasites created questions in those who discovered this phenomenon several decades ago, and also among those who research Komi folklore today. Moreover, these rituals cast doubt on genre-wise categorisation of lamentations. Indeed, it might be that in ward-off rites, it is not the lamentation at all, but instead, a charm - a genre used to protect from and expel all kinds of sources of danger, including insects, predators and, among many cultures, even diseases or illnesses. The combination - magic and lamenting - is not very customary. In the current article I attempt to introduce the use of laments in magic. Magic is concealed, it is not talked about loudly, and not practiced publicly; this is why it is not easy for researchers to discover magic (Virtanen 1988: 239). The concealed magic component of Komi lamentations for the dead is, in my view, revealed in their relation with the recordings of warding-off rites. Upon the comparison of the texts of the latter with lamentations, the categorisation of these texts and the use of laments in expelling parasites and weeds, seems logical.

\section{KOMI LAMENTATIONS FOR THE DEAD}

A number of researchers have studied the funeral customs of the Komi (e.g. Nalimov 1907; Semenov 1992; Teriukov 1979, 1984; Limerov 1996). Up until today, the lamentations of the Komi, however, have been the object of research on extremely infrequent occasions, differently from their other aspects of oral tradition. When talking about burials, the informants, from among the Komi, underline that lamentations were performed repeatedly during the funeral: at home, on the way to the graveyard, in the graveyard until the coffin was closed, and while the coffin was lowered into the grave, etc. In 1939, lamenter Platon Kalisa presented the following lamentations to the collector, Ivan Osipov: When mother lies on the table (195 lines), Lament when carrying the coffin out and on its way to the grave (60 lines) and Lament on the grave (70 lines) (Osipov 1986: 74-93). There are not many recordings of lamentations, used at different 
stages of ritual practices. Still, in the archive documents of the later period, lamentations have been marked by the performers or, more evidently, by the collectors, according to the addressee, e.g., To mother, To husband, To father, etc. The article published by the renowned Komi collectors and researchers, Anatoli Mikushev and Fedor Plesovskii in 1979 can be considered to be the only source material describing the lamentations from different Komi areas. The authors of the article provide the following description with regard to Komi burial laments: "(Burial) lamentations express the materialistic worldview, and are far from any kind of mysticism, "the world beyond" is not at all mystical. The images of the life beyond the grave are generally not reflected in lamentations and all details within lamentations are there for the main aim which is to express the endless grief of the family who has lost the breadwinner, a dear and beloved person" (Mikushev \& Plesovskii 1979: 48). It might be that materialism and the absence of mystics were indeed intrinsic in the Soviet folkloristics of the time, whereas during this era, when folkloristics was oriented at philology and used the terms and notions of literary criticism, materialism was actually a characteristic of insufficient artistry and aestheticism. The fact that there were no descriptions of the passage to the beyond and afterlife, indicated that burial lamentations are not the core of archaic, mythological cultural strata of the Komi.

Yet the bearers of traditions did not evaluate the burial lamentations from an artistic perspective and, likewise, did not solely associate these with the possibility to express one's feelings, and attributed a magical power to the wailings. According to the 1979 report by Komi folklorists, the participants in the expedition came across an astonishing phenomenon during the recording of the burial lamentation - not that the Komi women had forgotten lamenting, quite the contrary - the lamentations were in active use and people believed in their power. The lamenters categorically refused, as a response to the relevant request by the collectors, to perform the lamentation, or even fragments or retelling thereof, because they believed that performing the lamentation outside a certain ritual practice would cause someone to die. One of the wellknown lamenters in the neighbourhood, K. Turkova, dictated the text of the burial lamentation to her student grandchild (girl). Soon after this, another one of her grandchildren (a boy) was killed. The grandmother associated the slaughter with the fact that she had "performed" the burial lamentation outside the ritual (KSC RA fund 5 inv. 2 f. 209a). The fact that lamenting outside the ritual is not safe is also evident in the procedure шог пыркӧдӧм'shaking out the grief', which means that the clothes worn during lamenting were shaken and beaten afterwards (NMKR DF inv. 198; Plesovskii 1968: 123). 


\section{THE MAGIC OF LAMENTATIONS}

The concept of magic is treated differently by researchers, for example, Laura Stark, in her treatise determines magical as follows: "supernatural means to cause harm to others, to protect someone from supernatural damage, the spelling of charms and healing from illnesses" (Stark 2006: 45). Elena Levkievskaia makes a distinction between three forms of magic in charms: tangible, actualisational and verbal (Levkievskaia 2002: 334). Word magic is usually associated with charms, the words of which are believed to be "a weighty means to achieve a certain goal; [---] a medium that cannot be opposed by natural laws or the will of an individual" (Poznanskii 1917: 102).

Jouko Hautala, a Finnish folklorist, has expressed his opinion that the existence of any kind of poesy is conditioned by magical factors and the entire primordial poesy can be conditionally referred to as charms (Hautala 1960: 40). When discussing the (magic) power of the word, the researcher Hautala turns to the genre of lamentations. He writes that the magic of wedding lamentations lies in protecting the bride from the danger that primarily proceeds from the deceased of her family, whereas the burial lamentations soften and erase the deceased's doubt as if the living ones could be blamed for his/her death. The researcher is also of the opinion the expression of mourning and grief is magical in nature, as when the dead person hears being mourned, the dead person would not be hostile against the living ones (Hautala 1960: 39).

Folklorists Valeriia Eremina and Kirill Chistov have specified the connections between Russian burial lamentations and magic. According to V. Eremina, charms are being intertwined in Russian lamentations; K. Chistov underlines the magic function of burial lamentations (Eremina 1981: 70-86; Chistov 1994: 267-274). Both researchers reach their conclusions on the basis of the motifs, existent in lamentations, where the lamenters ask, in an imperative form, the coffin cover to open and the deceased person to rise. According to K. Chistov, the magical function of these motifs transformed into an emotional rhetoric method as early as during the 19th century and at the beginning of the 20th century (Chistov 1994: 273).

The universal all-embracing term magic (magical) attains concreteness when placed in the frames of performative utterances, language, as presented by John Austin, the analytical philosopher in this book How to Do Things with Words (Austin 1986). When contemplating the diversity of language use, Austin came to a conclusion that there are a number of utterances that are not merely said, but are also used to do something (Austin 2006: 264). He suggested such utterances be referred to as performative, without describing the exact possi- 
bility to make a distinction between constative and performative utterances. Austin also presented utterances as three-level compounds wherein locutionary, illocutionary and perlocutionary acts take place. Later on, his idea was used in developing the speech act theory (mainly in the case of the illocutionary act which adheres to a certain force which is revealed in speaking) (Austin 1986: 100; Searle 1986: 151-1969). The subject matter for the speech act theory was everyday speech, and naturally, magic was not borne in mind while referring to the power of words.

Activity-based aspect of language has been studied for a long time in the case of anthropology of linguistics and folkloristics. The researchers have repeatedly noted that folkloristic performances do not merely describe but also confirm, organise, create and transform the world (Siikala 1994: 68; Piela 1988; Adon'eva 2004). Performativity is also one of the key words in Lotte Tarkka's monograph Rajarahvaan laulu. Tarkka observed the Karelian folk songs of the White Sea as a speech act "used as a mediation to speak about the surrounding world and attempting to influence this" (Tarkka 2005: 11). Word magic, the power of words equals with activity, this was earlier mentioned by a number of folklorists in connection with charms and this is a conspicuous example of the performativity of folkloric language. Nevertheless, it is not only the charms that can be treated as performative. Tarkka is of the opinion that a specific way of performing is intrinsic to any genre, not only to a ritual one (Tarkka 2005: 386).

\section{SPECIFIC USE OF WORDS AT LIMINAL TIMES}

Burial lamentations of the Komi, and also of other peoples, are a particular form of communicating with the dead. First, the lamenters make abundant addresses to and ask rhetoric questions from the deceased. When addressing the dead, the lamenters use specific expressions such as вӧр пу йылысь лэдзысьӧй, ва пыдӧсысь лэптысьӧй, шондібанӧй чӧскыд йӧла матушкаӧй, 'descending/bringing down from the tops of my trees my sun-faced and sweet-milk mother' etc., conveying an exclusively positive and respectful attitude, the veneration of the living towards the dead. The appearance related features and social status of the deceased is comprehensively praised and lauded when addressing them in lamentations. K. Chistov has said about the addresses in Russian lamentations, that the paraphrased names used to refer to the deceased, the bride and bridegroom, are connected with the "prohibitions to protect the lamenter and other members of the family from the further impact of evil powers, the first manifestation of which had been the death of the person 
who is being grieved for" (Chistov 1960: 13). An entire system of paraphrased metaphors to be used for kinship relationships has been worked out in Karelian lamentations. The researchers of these lamentations support K. Chistov's opinion that it is a taboo to mention the actual name of the person (Stepanova 2004: 7). Though, according to Unelma Konkka, the taboos had lost their power yet the metaphors had obtained a poetic meaning in the language of lamentations (Konkka 1975: 170-180). The traditional motif in Komi burial lamentations is the grief of departure, whereas in the archived Komi lamentations, there are no verbal markers referring to communication with the dead ancestors, no motifs of passing on greetings to the dead relatives, all of which are intrinsic of the lamenting tradition of Northern Russia, Karelian and Ingrian areas (see, e.g., Konkka 1992: 117-119).

Yet in connection with the magical power and performativity of lamentation, I would like to draw attention to funeral lamentations which at first glance are the most neutral ones and evidently reflect this materialism that earlier caught the eye of the researchers of Komi folklore. These mentioned motifs as if describe and state as to what is going on in the ritual. In these utterances, the speaker uses reflexive pronouns "I" and "we", however, there is no data indicating to the fact as if the lamentation was performed by many women at a time. In this case the pronoun "we" would tell that the lamenter, instead of talking solely on behalf of herself, actually does this in the name of other participants in the ritual. The predicate of these utterances characterises the activities that the "I" is performing at the moment or intending to do so. One verb can be repeated and form an entire section in the lamentation.

One of the most typical stating utterances is ме мӧдӧда 'I send'. Indeed, there is a difference when comparing this with the rhetoric question, intrinsic of lamentations, where do you go, where are you going, where are you preparing yourself for, etc. In the latter, the utterance is formed in the way as if the deceased would go to the world beyond in his/her own free will. The words " $I$ send you / we send you", the performers depict the sending as if initiated by the living. These two utterances can be observed as evidence of an ambiguous attitude towards the deceased. On the one hand, the cult of ancestors and fear of the dead gives rise to utterances according to which the dead person would get him/herself dressed and prepares for the journey, and leaves him/herself, etc. He/She is the one going on a journey, and the participants perform as the ones passively sending him/her away. Yet on the other hand, with an aim to restore order in the world, the living ones need to act themselves, and by doing so they transform the ritual action of the deceased into a passive object.

In lamentation the deceased are sent from this world to the world beyond. The characteristic features of this world are revealed by way of the following 
concepts: light, will, white, free, warm. The world of the living may be denoted in lamentations by way of the expressions such as вӧльнӧй свет 'the free world', вӧльнӧй вӧля 'freedom, free will'. In lamentations, the notions of the worlds are often of deictic character, thus, the world of the living can be denoted in burial lamentations as таладор сьвет, тайӧ му'the world of this side, this land', and when referring to being in this world, the phrase татӧн 'here' is used. To depict the world beyond, opposition of deictic terms is used: this that, here - there, from here - to there. For example, it says, in a lamentation mourning the dead mother: сэтчӧ вӧд тэӧй мунан да 'there you go, yes' (Osipov 1986: 75). In fact, deictic signifiers do not have a specific content and instead, this is determined by the circumstances of the spoken act message. There, as an opposite of here, denotes any place farther away from here. The metaphors, used in lamentations to denote the world beyond, are expressions wherein the word indicating a location is formed with the suffix - тӧм. This grammatical form of the nouns in the Komi language refers to the absence of something, giving the meaning of imperfection of an action, or lack of knowledge - that the activity was not completed. The place where the deceased are sent away in lamentations is marked by expressions such as пельӧн кывлытӧмин 'the place the ears have not heard of', синмӧн адзывтӧмин'the place eyes have not seen', туй дженьдытӧмин 'the place where the road is not becoming shorter', туй оттӧмсьытӧмин 'the place where the way does not become narrower'. These metaphors are not unambiguous, and obtain different meanings when communicating with the deceased. The expression пельӧн кывлытӧминӧ simultaneously acquires the meaning "send to the place of which my ears and your ears have not heard of", and also "the place where you and I would not hear about each other, from where the sounds would not be heard in "here"'. What it means is that the dead person is sent to a place out of the reach of auditory and visual senses. The living can send the dead to a long and wide road that leads to eternity where "the road does not shorten and the road does not become narrower" and from where there is no way back or further. This idea is realised in the following formulaic motif:

\section{Кузь туй ме мӧдӧда дженьдытэминэ. \\ Ота туй ме мӧдӧда оттӧмсьытцминэ.}

I send you to a long road where the path would not become shorter.

To a wide road I send you where the path would not become narrower.

Traditionally, this given motif would proceed as follows:

Водзе ме мӧдэда мунтэминэ нин,

Бӧре ме мӧдэда костэминэ нин! 
Farther I send you from where there is no way on, Back I send you from where there is no return.

(Mikushev et al. 1994: 75, No. 18, 76, 18b)

In general, love is being expressed towards the deceased in all possible ways and in the unwillingness to depart; even reproaching the deceased for leaving the others behind. However, in the given example, the lamenter explicitly words her thought: she sends the deceased person to the way in order that he/ she would not return. Such formulae can also be noted in the lamentations of the Izhma-Komi. Maybe, it is the reversed prosody of the verse, intrinsic of Izhma-Komi lamentations that makes it possible to convey this idea, particularly in the tradition of the given area, the word at the beginning of the utterance would match together with the last word in the phrase. Lamenters say "back I send" but they actually bear in mind "I send to there from where is no return". As a result of such an intentionally "wrong" word order in the utterance, the direct idea is encoded in the composition of the line of verse.

Besides the utterances "I send you" there are also motifs, intrinsic of burial lamentations, conveying the idea of relocation and of placing the deceased somewhere. In these motifs, the focus is on the verbs put, place, followed by a word denoting the situation. For example, in lamentations, the "I" says that she puts or places "him/her" under a thick layer of soil, "under the twelve layers of ground". In burial lamentations from Udora, it says:

\section{Муыслы да му пыдӧсас пуктаме, \\ Ваыслы да ва пыдӧсас пуктаме, А пуыслы да пу сьӧмӧсас пуктаме / \\ Into the earth, underneath the ground we place, Into the water, underneath the water we place, Into the tree, in the heart of the tree we place / (KSC RA fund 1, inv. 11, r. 291)}

As the world of the living is on the surface of ground, earth and water, the placing of the dead under the soil and water can indeed be understood as maximum removal from the world of the living. In the above fragment, the expression "into the tree, in the heart of the tree we place" can be interpreted as a metaphor for putting the dead in the coffin, as when making a coffin, the core of the tree was carved out (Belitser 1958: 147). Besides the fact that the places to where the deceased are sent or placed, these locations are also visually unreachable and soundproof, as far as possible from the world of the living, the lamentations also contain the ideas of creating obstacles, e.g. utterances regarding a high mountain with a stone wall, and closing the destination where 
the deceased had gone, with, e.g. "a wooden and German lock" (Mikushev et al. 1995: 170, 173). In Russian and Karelian lamentations, it is customary to refer to the grave as a new dwelling, whereas in Komi lamentations, the grave is also denoted with the metaphor of being a house, and, in addition, as a locked place (Stepanova 2004: 91; Rakhimova 2005: 109-119).

Descending into the grave and putting the dead in the coffin can be conveyed with a metaphor of a dark monastery, which, in my opinion, originates from the association of being imprisoned in a monastery.

Сыра нин пукта да матюраэ,

Квайтэ нин пукта да пӧлыс косме,

Джуджыд нин пемыд да манастыре,

Уусянь нин буксэн да букшайтанінэ,

Выысянь нин тшакен тшаксяйтанінэ.

In the moist soil I put you,

Between the six boards,

In a deep and dark monastery,

A place already moulding from underneath,

A place covered with fungi on top.

(Mikushev et al. 1994: 75)

\section{CHARMS AND LAMENTATIONS IN WARDING-OFF RITES}

In 1960, the collectors of Komi folklore in Mutnyi Materik village, Komi Republic, came across the so far unknown singing performances, described later as the "forgotten genre of folklore". These texts, pursuant to the observations of the collectors, reminded of lamentations, considering their musical and poetical characteristics, and the terminology used by the bearers of tradition. However, when attempting to ascertain the context of performing these texts, the researchers needed to contemplate as these lamentations were performed, in the words of the informants, when expelling bedbugs from the house and warding off burdock from the fields (Mikushev et al. 1994: 11).

The tradition of expelling insects was known long before the "discovery" of these texts. A. Sidorov, a Komi researcher, referred to the warding off of bedbugs and cockroaches as magical rituals and published the description thereof in his monograph Charms, witchcraft and evil eye of the Komi people (Знахарство, колдовство и порча у народа коми), first published in 1928 (Sidorov 1997: 28). According to oral records, rituals to ward off burdock were carried out before Midsummer (St. John's Day) and autumn harvesting, bedbugs were expelled prior to Christmas, St. John's Day and St. Peter's Day, and if neces- 
sary, also at other times. The process to eliminate burdock from the fields was as follows: куим ӧкмыса 'three times nine' burdocks were pulled out with roots, tied together, and then one group of women would take the burdock to the river, walking backwards, and the others would beat the burdock with whips (KSC RA fund 1, inv. 11, r. 206). According to another story, the largest burdock was pulled out in the field and thereafter planted on the road (KSC RA fund 11, inv. 11, r. 186). At darkness, the burdock could also be cut with a fire poker (SyktSU FA 1573-34). There were several methods to get rid of bedbugs: put on a woodchip, the bedbugs were let go downstream the river (Sidorov 1997: 81-82); a bundle of bedbugs was put inside the birch-bark shoe and then taken to the crossing of three roads (e.g. SyktSU FA RF 12-XVI-40); bedbugs were "buried" in the graveyard (SyktSU FA 1911-32, 34)

In general, such "bewitching" seems to be quite appropriate to use charms therein, however, the texts that were read during the ritual practices (the narrators bear in mind the charms) or asked (here the narrators bear in mind dialogue-charms) are actually the most typical lamentations to bedbugs and burdock. To illustrate the tradition and the relevant lamentations, I would hereby present the material recorded (written down in 1991, from the inhabitants of the Kozhva village, Pechorskii district, Komi Republic. The oral Russian-language text, written from the Komi language guide, has been made more legible.

Навстречу Иванову дня клопов хоронили. Собирают три раза девять штук, собирают три раза по девять шттк. В коробку спичек положишь да завернёшь, да к кочерге привяжешь. Да эту кочергу возьмёшь. Старик кочергу возьмёт да на кочергу сядет, как будто бы на лошади. А сзади толпа собралась, да как они плачут, как будто поплакивают они <...>. Пойдёт по деревням, плачет со слезами: “Прощай, Клоп Клопович, Прощай, Клоп Клопотовна”. Много людей собирается, на могилу все пойдут. Где хоронили покойника, туда же, на кладбище. Это в Иванов день, навстречу Ивана, 6-го...

Bedbugs were buried before St. John's Day. Three times nine bedbugs are collected, three times nine bedbugs. You put them in a matchbox and wrap them up, tie them to the fire poker. And then you take this fire poker. An old man sits astride on the fire poker, like on a horse. People would gather behind him, and how they cry, almost like lamenting [---]. Goes around the village, in tears: "Farewell, Bedbug, son of Bedbug, farewell, Bedbug, daughter of Bedbug." A lot of people gather, all go to the grave, where the deceased are buried, to the same graveyard. This is on St- John's Day, before the feast, on the 6th... (SyktSU FA 1911-32, 34) 


\section{SPECIFICITY OF WARD-OFF TEXTS}

The verbal part of ward-off ritual, performed as lamentation (or, in some occasion, as singing), according to the informants, is of communicative character: with bedbug or burdock as addressees. To address the bedbug and burdock, the performers use periphrases, which, in their structure and formation, are similar to the addresses used in burial lamentations. As a comparison: bedbug чӧскыд вирес юись 'the one who drinks tasty blood', mother - чӧскыд йӧлӧн вердысь 'the one who feeds with tasty milk'. When using the words ludik 'bedbug' and jön 'burdock', these are always accompanied with epithets of positive colouring, e.g. šondibanöj ludiköj 'my Sun-faced bedbug'. Frequently, the lamenters commence their performance with indeed such addresses (highlighted in bold):

Шондібанӧй дай лудікӧй,
Чӧскыд ун паледысей дай.
Первой гажедысей.
Чӧскыд вирес юысей дай,
Кор нӧ ме тэнэ сэсся аддзыла,
Зэв же нин тэ жаль да,
Кор нин эся ме тэнэ аддзыла,
Некор ӧд ог ме аддзыл.
Маег йылэ, ой, тэ кайин
Да-й кынман.

You my Sun-faced bedbug, You who wakes me in my sweet sleep, My first entertainer.

The one who drinks my tasty blood, yes, When shall I see you again, I feel so sorry for you, yes, When shall I see you again, Never again shall I see you now, Oh, you climb up on a stake And freeze to death.

(KSC RA fund 5, inv. 11 r. 172) (103)

In order to add more respect to the utterance, bedbug and burdock can be called after their first name and father's name Лудык Лудыкович(Ludyk Ludykovich) 'Bedbug, son of Bedbug', Тотарин Тотаринович(Totarin Totarinovich) 'Tatar, son of Tatar'. By the way, it is not at all accidental that the word татарин (tatarin) 'Tatar' is used as an epithet or metaphor for burdock. In wedding lamentations of the Komi, Tatarians are considered to be the kinship of the bridegroom, and until a certain moment in the wedding, they are foreign and dangerous for the bride, i.e. the ones coming from the other world.

The specific feature converging these texts to these of lamentations is a group of verbal expressions providing the speech with a tint of grieving. Grief about departure may be expressed in rhetoric questions to bedbug and burdock: how shall I live from now on, who will now wake me up early, when shall we meet again, etc. Likewise, the performers may be compassionate about their future, e.g., being afraid they might die of cold and hunger. They can ask 
forgiveness from bedbug and burdock, from their "brothers-sisters and the entire family". It is also characteristic of the ward-off texts to use phrases with which the performer of the rite as if comments or describes the stages of the ritual. For example, "I" or "we" tell the bedbug that they will now wrap it in a rag and take it to the crossing of three roads, put it in a bag and take it away, send or intend to send it on the way and put it in the ground. The ward-off utterances, stating the ritual, again remind of burial lamentations where it is told that the deceased is sent away from home, sent on the way, put in the coffin, placed in the soil, etc.

These utterances of ward-off rituals may be presented as integral compositional blocks. The following example introduces the phrases said by the charmer to go with the main elements of the ritual: the start to sending off the bedbug, bedbugs are collected in a box, three times nine bedbugs, they are sent to the earth, sent forever, buried, in order for them not to come out, in order for them not to come back, not to return in the future.

Эжтыр луд лудыкес мӧдам мӧдэдны бур рӧдвужъяснаснум,

Эжтыр луд лудыкес мӧдам мӧдэдны бур вок-чойнаснум,

Куим ӧкмыс тіянтэ кучам чукартны кӧребыс пытшке,

Сэсся нин тіянтэ кучам сыра земля нуэдны матюра пытшке,

Картыр рӧдвужъен ті помласьныд мӧдам укеренитны бур рӧдвужъяслы, Эжтыр Луд Лудыкес мӧдам нуэдны ті помныд бур вок-чойнаснум.

Ас олыг сэсся ми мӧдэдім векыс кеже,

Водзе нин Лудікес сэсся ми сэчче пуктім вотэм вылэ,

Бӧре нин Лудікес сэсся ми пуктім костэм вылэ,

Сыра земля ми пуктім петтэм вылэ...

We intend to send the bug, the bedbug on the journey, sheets full of good family,

We intend to send bug the bedbug on the journey, sheets full of good brothers and sisters,

Three times nine we collect you in a box,

Then we start sending you to the bosom of mother earth ${ }^{2}$,

Because of you we uproot a nest full of good family,

Because of you we take the bug the bedbug sheets full of good siblings.

We sent then for the lifetime, forever,

There we put the bedbug, in order for it not to return,

Then we put the bedbug in order for it not to come back,

Into the soil (=grave) we put, in order for it not to come out...

(KSC RA fund 1 inv. 11 r. 206) 
The widely spread opinion with regard to lamentations, i.e. these being primarily associated with tragic circumstances and the expression of grief for the passing away of the close ones, did not allow the researchers to associate lamentations with warding-off rituals (Alekseevskii 2007: 267-269). The texts, expressing benevolence towards the vermin, were preformed in a mournful manner, with simultaneous crying, and the entire ritual seemed to be in every way contradictory to the main aim of this tradition - to ward off vermin and protect the people and their wellbeing. Likewise, the connection between lamentation and warding-off rites has not been observed in the system of Russian folklore genres, on which the folklorists relied. The context of the performance, the magical number of bedbugs and burdock (three times nine) in the rituals, noted by Anatolii Mikushev, the laudatory, pleasing tone of the addresses and apologies to the objects of being expelled, made the researchers think that the texts operate in this ritual as charms and conjuring. Functional approach and an attempt to include popular folk names and presenting these in the songs gave rise to the following key words with regard to this text group: charm-songs, songcharms, lamentation-charms, charm improvisations, songcharms of agrarian cycle (e.g. Konakov 1993; Mikushev 1973, Filippova 1996).

However, pleading, threatening, disparaging and commanding formula, intrinsic of bewitching ones, are not to be found in these texts. It became obvious that the texts belonging within warding-off rituals are actually converging with lamentations, both with regard to their style, poetic specificity, manner of performing and musical characteristics. Likewise, the informants also confirmed that the performing of the texts in warding-off rituals is actually lamenting. Communication with the addressees of the text - bedbugs and burdock - is analogous to lamentations sending off the deceased: it is customary to only talk good about the deceased, and ask him/her for forgiveness, it is obligatory to show the deceased, by way of benevolent verbal and physical form, that he/ she is being mourned.

The elements, within the logic of performing lamentations, can also be noticed within the context of the ritual with vermin - one of them being the fact that terminologically, the warding-off rite, particularly in case of bedbugs, was referred to as sending away and funerals (ludik gualöm, lidik dzeböm), and, based on the narratives, this burial was actually conducted as a real-life activity. The insects and weed are not destroyed during the ritual, instead, they are "sent" from one space to another. The places, where the bedbug or burdock actually are in the course of the ritual, are associated in the Komi culture with the world beyond or with the way leading to the other world, being liminal areas, the mediators between the two worlds. Within the expelling rites, bedbugs end up in the river, crossing of three roads, be tied to the 
cart of a beggar; burdock can occur in the river or be planted on the road. The tradition encompassed a number of activities and artefacts with protective properties. For instance, when expelling bedbugs, it is necessary to ride on a fire poker, making three circles around the house. In many rituals, drawing a circle is a method to create a closed space, which cannot be penetrated by the sources of danger (Levkievskaia 2003). Reverse activities have been recorded in "taking out" the burdock, e.g. the lamenters, when holding the plant, moved backwards. In this, Anatolii Mikushev has noticed a parallel with the burial customs of the Nenets, neighbours of the Komi, where, in order to protect oneself from the hostile power, and blur the traces, people walk backwards (Mikushev 1973: 38). Likewise, funeral customs of the Komi also entail a whole complex of reversed actions - committed to protect oneself from any influence possibly coming from the deceased -, e.g., turning around or inverting objects and artefacts, plaiting a reversal braid, moving counter-clockwise around a fresh grave, prohibition to look back when leaving the graveyard, etc. Concerning the items used in the ritual, I would like to highlight the fire poker. I am of the opinion that the poker is involved in both of the above-described rituals in order to protect the person performing these ritual activities, at the moment of encounter with the world beyond. The protective power of the iron poker is indeed confirmed in a traditional children's game where the house spirit, invited from the cellar during the play, was scared off and sent back to its location with the help of the poker (Nesanelis 1993: 96-98).

Still, what remains disputable, genre-wise, are the motifs of warding-off texts where the performer, on behalf of herself, talks about what she is doing. Such utterances are extremely intrinsic in the case of charms (e.g. Viljakainen 2009, Piela 2005). Bearing in mind the fact that these texts are performed during the warding-off ritual, the words said to bedbugs and burdocks are selfevidently associated with charms.

Nevertheless, according to reference literature, similar motifs are also present in the burial lamentations of the Komi, and not only there. Tatiana Bunchuk, a linguist, had defined "syntactic constructions, with the predicate in the central position" in Komi wedding lamentations, work songs and other lamentations. She is of the opinion that the relevant Komi texts are similar to the vita herbae / rei texts, used in Slavic culture as an apotropaic magical agent, or the one with productive character. Bunchuk refers to the vita herbae I rei texts as the ones contributing to restoring the balance of world order, when the representatives of the world beyond have disturbed or are threatening the order of the world, during the liminal stages of human life (Bunchuk 2006: 113-126). 
Ulla Piela talks about healing narratives (parantavia narratiiveja), when referring to the text groups in Finnish-Karelian charms narrating of the ritual wherein the healer tietäjä talks about his activities and wishes within the charm text (Piela 2005: 13). Proceeding from the above, the utterances in the style of "I do something" in warding-off rites function as performative narratives that send away the bedbug and burdock and create a world without vermin. Similarly, the performer, who is authorised to represent the interests of the entire group, creates performance narratives, by way of imitating and doubling his/ her actions with words. The interpretations of the metaphors denoting the locus to where the deceased are sent or placed make it possible to conclude that performativity, the magic of burial lamentations is all about the capability of the lamenter to place the deceased in the place where it is not possible to make oneself heard or visible, from where there is no way back or forth, and to close this place. Thus, the texts performed at funerals and warding-off rituals have similar performativity, in addition to the recitative nature, poesy and common folk-related terminology; in other words, they have a uniform magical foundation. As a whole, these characteristics make it possible to use the same terminology in the case of texts utilised at expelling rituals, and the ones performed in funeral tradition.

The given interpretation does not pretend to be an exhaustive characterisation of lamentation magic. Performative interpretation thereof provided an opportunity to see the so far unknown facets of burial lamentations and mould a standpoint with regard to the genre of warding-off rites, and to partially understand the logic of lamenting in expelling rituals.

\section{NOTES}

1 Radunitsa [радуница] - a pagan spring feast associated with the cult of ancestors among the Eastern Slavs. After conversion to Christianity, this feast was celebrated on the first Sunday after Easter, or on the following Monday or Tuesday. Food and drinks are taken to the graveyard, to symbolically treat the deceased. (Dal; Hronos).

${ }^{2}$ Metaphoric formula sõra zemlja mat'ura, borrowed from Russian.

\section{ARCHIVAL SOURCES AND ABBREVIATIONS}

inv. - inventory

r. - record

f. - file 
KSC RA = Komi Science Centre research archive. [NA KNTs - Nauchnyi arkhiv Komi nauchnogo tsentra.]

NMKR DF = National Museum of Komi Republic, department of funds. [OF NMRK Otdel Fondov Natsional'nogo muzeia Respubliki Komi.]

KSC RA fund 1 inv. 11 r. 291 = Udora district, Liaziuv village, A. F. Ershova (b. 1884). [NA KNTs f. 1 op. 11 ed. khr. 291 = KR, Udora r-n, Liaziuv g., Ershova A. F. 1884 g.r.]

KSC RA fund 5 inv. 2 f. $209 \mathrm{a}=$ Materials of the expedition to Luza district, Letka in 1976, collected by I. Rochev. [NA KNTs F. 5. Op. 2. Delo 209 "a' = Materialy fol'klornoi ekspeditsii v Letku Priluzskogo raiona v 1976 godu. Sobiratel' Iu. G. Rochev.]

KSC RA No. 172 (103) = Ust-Kulom district, Sotchemvyv village, collected by Murav'eva, written down in 1964. [NA KNTs No. 172 (103) = RK, Ust'-Kulomskii r-n, d. Sotchemvyv. Zap. 1964, zap. Murav'eva.]

KSC RA fund 1, inv. 11, r. 206 = Ussinsk district, Novikbozh village, A. Kaneva (b. 1889), M. Bessonova (b. 1912), M. Kaneva (b. 1905), written down in 1967. [NA KNTs f.1 op.11 d.206: RK, Usinskii r-n, d. Novikbozh. Kaneva A.N. 1889 g. r., Bessonova M. I. 1912 g. r., Kaneva M. M. 1905 g. r.; zap. 1967 g.]

NMKR DF inv. 198 = Materials collected by A. Nalimov, in the National Museum of Komi Republic, Department of Funds. [OF NMRK Inv 198. = Materialy. Sobiratel' Nalimov V. A.]

SyktSU FA 1911-32, 34 = Syktyvkar State University folklore archives, Pechora district, Kozhva village. A. Arteeva (b. 1907), A. Semiashkina (b. 1920), written down in 1991 [FA SGU 1911-32, 34 = RK, Pechorskii r-n, d. Kozhva. Arteeva A. P. 1907 g. r., Semiashkina A. F. 1920 g. r.; zap. 1991 g.]

SyktSU FA 1573-34 = Kortkeross district, Vylib village, E. A. Misharina (b. 1930) [FA SGU 1573-34 = RK, Kortkerosskii r-n, d. Vylib. Misharina E. A. 1930 g. r.; zap. 2001.]

SyktSU FA 12-XVI-40 = Ust-Kulom district, Kerchomia village, A. Samarina (b. 1916), written down in 2000. [FA SGU RF 12-XVI-40 RK, Ust'-Kulomskii r-n, s. Kerchom'ia. Samarina A. E. 1916 g. r.; zap. 2000 g.]

\section{REFERENCES}

Adon'eva, Svetlana 2004. Pragmatika fol'klora. Saint Petersburg: Amfora.

Alekseevskii, Mikhail 2007. Severnorusskie pokhoronno-pominal'nye prichitaniia kak akt kommunikatsii: k voprosu o pragmatike zhanra. Riabininskie chteniia 2007. Materialy V nauchnoi konferentsii po izucheniiu narodnoi kul'tury Russkogo Severa. Petrozavodsk, pp. 267-270.

Austin, John (=Ostin, Dzhon) 1986. Slovo kak deistvie. Novoe v zarubezhnoi lingvistike 17. Moskva: Progress. [Austin, John 1962. How to do things with words. Oxford UP, New York: Oxford University Press].

Austin, John (=Ostin, Dzhon) 2006. Tri sposoba prolit' chernila: filosofskie raboty. St. Petersburg: Izdatel'stvo Sankt-Peterburgskogo universiteta. 
Baranov, Dmitrii 2005. Obrazy veshchei. O nekotorykh printsipakh semantizatsii. Antropologicheskii forum 2, pp. 214.

Belitser, Vera 1958. Ocherki po etnografii narodov komi XIX - nachalo XX v. Moscow: Izdatel'stvo akademii Nauk SSSR.

Bunchuk, Tatiana 2006. Komi trudovye pesni i prichitaniia kak raznovidnost' tekstov Vita herbae et rei. Narodnaia kul'tura evropeiskogo Severa Rossii: regional'nye aspekty izucheniia. Sbornik nauchnykh trudov. K 100-letiiu kafedry fol'klora i istorii knigi. Syktyvkar: Izdatel'stvo SyktGU, pp. 113-126.

Chistov, Kirill 1960. Prichitaniia. Biblioteka poeta: Bol'shaia seriia. Leningrad: Sovetskii pisatel'.

Chistov, Kirill 1994. K voprosu o magicheskoi funktsii pokhoronnykh prichitanii. In: V. Petrukhin (ed.) Istoriko-etnograficheskie issledovaniia po fol'kloru. Sbornik pamiati S. A. Tokareva. Issledovaniia po fol'kloru i mifologii Vostoka. Moscow: Vostochnaia literatura RAN, pp. 267-274.

Dal = Dal', Vladimir. Tolkovyi slovar' V. Dalia on-line http://vidahl.agava.ru/ P190.HTM\#34858, last accessed on 10 April 2011.

Eremina, Valeriia 1981. Istoriko-etnograficheskie istoki “Obshchikh mest” pokhoronnykh prichitanii. Russkii fol'klor XXI. Leningrad: Nauka.

Filippova, Valentina 1996. Teoreticheskie problemy izucheniia pesennykh zhanrov komi fol'klora. Traditsionnaia muzykal'naia kul'tura naroda komi. Tezisy dokladov. Syktyvkar.

Hautala, Jouko 1960. Sanan mahti. [The Power of the Word.] In: J. Hautala (ed.) Jumin keko:Tutkielmia kansanruonoustieteen alalta. [Folkloristic research.] Tietolipas 17. Helsinki: Suomalaisen Kirjallisuuden Seura.

Honko, Lauri 1978. The Ingrian Lamenter as Psychopomp. Temenos. Studies in Comparative Religion 14, pp. 79-96.

Hronos $=$ Khronos - vsemirnaia istoriia v internete. Religii mira. Pravoslavie http:// www.hrono.ru/religia/pravoslav/radunica.php, last accessed on 10 April 2011.

Konakov, Nikolai 1993. Ot sviatok do sochel'nika. Komi traditsionnye kalendarnye obriady. Syktyvkar: Komi knizhnoe izdatel'stvo.

Konkka, Unelma 1975. Tabu slov i zakon inoskazaniia v karel'skikh plachakh. Problemy fol'klora. Moscow.

Konkka, Unelma 1992. Poeziia pechali. Karel'skie obriadovye plachi. Petrozavodsk: KNTs RAN.

Levkievskaia, Elena 2003. Slavianskii obereg. Semantika i struktura. Moskva: Indrik. Limerov, Pavel 1996. Mifologiia zagrobnogo mira. Syktyvkar: Komi NTs UrO RAN.

Mikushev, Anatolii 1973. Epicheskie formy komi fol'klora. Leningrad: Nauka.

Mikushev, Anatoli \& Plesovskii, Fedor 1979. Prichitaniia. In: A. Mikushev (ed.) Istoriia komi literatury 1. Fol'klor. Syktyvkar: Komi knizhnoe izdatel'stvo.

Mikushev, Anatolii \& Chistalev, Prometei \& Rochev, Iurii (eds.) 1994 [1967]. Komi narodnye pesni: Izhma i Pechora. Syktyvkar: Komi knizhnoe izdatel'stvo.

Mikushev, Anatolii \& Chistalev, Prometei \& Rochev, Iurii (eds.) 1995 [1971]. Komi narodnye pesni: Vym'i Udora. Syktyvkar: Komi knizhnoe izdatel'stvo.

Nalimov, Vasilii 1907. Zagrobnyi mir po verovaniiam zyrian. Khristianstvo i iazychestvo naroda komi. Etnograficheskoe obozrenie 1-2, pp. 4-23. 
Nenola, Aili 1978. Niin miä elän kui kylmäs sarajas. Inkeriläiset tilapääitkuvirret. [I live as if in a cold hay barn. Ingrian occasional laments.] Sananjalka. Suomen kielen seuran vuosikirja 20. Turku, pp. 75-103.

Nesanelis, Dmitrii 1994. Traditsionnye formy dosuga sel'skogo naseleniia Komi kraia (vtoraia tret' 19 - pervaia tret' 20 vv.). Syktyvkar: Komi knizhnoe izdatel'stvo.

Osipov, Ivan 1986. Viser vozhsa s'ylankyv"ias da moidkyv"ias. Syktyvkar: Komi knizhnoe izdatel'stvo.

Piela, Ulla 2005. Parantajan rituaalinen kosketus. [The Ritual Contact of the Healer.] In: S. Huttunen \& P. Nuolijärvi (eds.) Tahdon sanoa. Kirjoituksia kielen ja perinteen voimasta. Helsinki: Suomalaisen Kirjallisuuden Seura, pp. 11-31.

Plesovskii, Fedor 1968. Svad'ba naroda komi. Syktyvkar: Komi knizhnoe izdatel'stvo.

Poznanskii, N 1917 [1995]. Zagovory. Opyt issledovaniia proiskhozhdeniia i razvitiia zagovornykh formul. Petrograd: Tipografiia D. V. Orlova.

Rakhimova, Elina 2005. Izobrazhenie "zhilishcha" pokoinogo v karel'skikh i russkikh plachakh. Slavianskaia traditsionnaia kul'tura i sovremennyi mir. Sbornik materialov nauchnoi konferentsii 7. Moscow, pp. 109-119.

Searle, John R. (=Serl', Dzhon) 1986. Chto takoe rechevoi akt. Novoe v zarubezhnoi lingvistike. 17. Moskva. [Searle, John 1965. What is a speech act? In: M. Black (ed.) Philosophy in America. London: Allen \& Unwin, pp 221-239.]

Semenov, Viktor 1992. Traditsionnaia semeinaia obriadnost' narodov Evropeiskogo Severa: $k$ rekonstruktsii mifopoeticheskikh predstavlenii komi (zyrian). SanktPeterburg: Izdatel'stvo Sankt-Peterburgskogo universiteta.

Sidorov, A. S 1997 [1928]. Znakharstvo, koldovstvo i porcha u naroda komi. Materialy po psikhologii koldovstva. Sankt-Peterburg: Aleteiia.

Siikala, Anna-Leena 1992. Suomalainen šamanismi. [Finnish Shamanism.] Mielikuvien historia. Suomalaisen Kirjallisuuden Seuran toimituksia 565. Helsinki: Suomalaisen Kirjallisuuden Seura.

Stark, Laura 2006. The Magical self. Body, Society and the Supernatural in Early Modern Rural Finland. FF Communications 290. Helsinki: Suomalainen Tiedeakatemia.

Stepanova, Aleksandra S 1985. Metaforicheskii mir karel'skikh prichitanii. Leningrad: Nauka.

Tarkka, Lotte 2005. Rajarahvaan laulu. Tutkimus Vuokkiniemen kalevalamittaisesta runokulttuurista 1821-1921. [Songs of the Border-People: Kalevala-Meter Poetry in Vuokkiniemi Parish 1821-1921.] Helsinki: Suomalaisen Kirjallisuuden Seura.

Teriukov, Aleksandr 1979. Kizucheniiu pogrebal'nogo obriada Pechorskikh komi. Moscow: Nauka.

Teriukov, Aleksandr 1984. K izucheniiu pogrebal'nogo obriada komi-izhemtsev. Moscow: Nauka.

Viljakainen, Maarit 2009. Minnekäs mie siun manoan? Taudin Puhuttelut parannusloitsuissa. [Healing charms.] In: S. Knuuttila \& U. Piela (eds.) Korkeempi kaiku. Sanan magiaa ja puheen poetiikkaa. [A Higher Echo: Word Magic and the Poetics of Speech.] Kalevalaseuran vuosikirja 88. Helsinki: Suomalaisen Kirjallisuuden Seura. 